\title{
ESTUDOS DE DIREITO COMPARADO (I) O QUE É A "COMMON LAW", EM PARTICULAR, A DOS EUA
}

\author{
Guido Fernando Silva Soares \\ Professor Titular do Departamento de Direito Internacional da \\ Faculdade de Direito da Universidade São Paulo \\ Diplomata do Quadro Especial do Ministério das Relações Exteriores
}

Resumo:

$\mathrm{Na}$ introdução, o autor aborda o fenômeno jurídico como suscetível de ser descrito por princípios científicos (direito-ciência). Portanto, por metodologia científica, é possível realizar-se um estudo complementar dos grandes sistemas jurídicos da atualidade (famílias de direitos). Serão estudados os grandes traços da família romano-germânica dos direitos, em comparação com a família de "Common Lav". Após, examineın-se os três sentidos da expressão "Common Law": como um sistema típico, nascido na Inglaterra e que se espraiou pelo mundo de fala inglesa. Dentro deste sistema, os sentidos próprios de "Common Lav". como sendo um direito criado pelo juiz (em oposição ao direito escrito) e, historicamente, como o direito criado pelos Tribunais do Rei (em oposição àquele criado pelos Tribunais do Chanceler do Rei).

Especial ênfase é dada ao direito dos EUA, considerado como um sistema misto, entre a família dos direitos romano-germânicos e a "Common Lav"

Abstract:

In the introduction, the author treats the juridical phenomenon as susceptible of being described by scientific principles (law-science). Therefore, for scientific methodology, it is possible to take a complementary study of the great juridical systems of the present time (families of rights). The great lines of the Roman-Germanic family of the rights will be studied, in comparison to "Common Law" family. After, the three senses of the expression "Common Law" are examined: as a typical system, bom in England and that was extended by the world of English speech. Inside of this system, the appropriate "Common Law" senses, as being a right created by the judge (in opposition to the written right) and, historically, as the right created by the King's Tribunals (in opposition to that one created by the Tribunals of the King's Chancellor).

Special emphasis is given to the right of the USA, considered as a mixed system, between the family of the Roman-Germanic rights and "Common Law". 
Unitermos: sistemas de direito; common law.

Sumário:

1. Introdução.

2. Os Percalços do Comparativismo Jurídico.

3. Os Grandes Sistemas de Direito.

4. O Sistema Romano-Germânico.

5. Os Sentidos da Expressão "Common Law":

5.1. "Common Law" e "Equity Law";

5.2. "Common Law" e "Statute Law";

5.3. "Common Law" e "Civil Law".

6. Conclusões.

1. Introdução.

Atividade instigante e extremamente enriquecedora no universo do Direito, entendido como Ciência Jurídica, é a comparação entre sistemas jurídicos. Os termos de comparação, tomando-se por base um determinado sistema jurídico nacional, vigente no momento da análise, podem ser considerados em duas grandes perspectivas: a. da sucessividade, no tempo, de dois sistemas, partindo-se do pressuposto de que o direito anterior teria ficado cristalizado, e que o direito tomado por referência, se originou daquele (assim, os estudos de Direito Romano, ou do sistema português, das Ordenações régias portuguesas e demais normas, antes do Brasil independente, de um lado, e o atual Direito pátrio) e b. da concomitância de dois sistemas, ambos vigentes no momento da análise: de um lado, o sistema de um país estrangeiro, e de outro, o sistema tomado por referência. No primeiro caso, que melhor seria descrito como um fenômeno de História do Direito, toma-se um sistema vigente em épocas anteriores, e a comparação se faz com a época atual, onde o interesse residiria na evolução histórica de um mesmo organismo normativo, nas suas etapas estanques no tempo; no segundo caso, tomam-se dois sistemas distintos, vigentes em países distintos, num mesmo momento histórico, e as comparações se efetuam a partir de uma metodologia científica rigorosa, onde apareceriam elementos comuns e os diferenciados.

Contudo, o comparativismo jurídico tem outra finalidade, além do simples conhecimento científico de outros sistemas, de outras "famílias" de Direito: 
a importante tarefa de auxiliar o aplicador do direito, a fazer valer, num sistema jurídico determinado, os efeitos de um instituto jurídico desconhecido neste, e que necessitam ser reconhecidos, sob pena da denegação de justiça (verdadeira aberração, em qualquer situação factual apresentada a autoridades legítimas e constituídas num regime democrático, que tenham por incumbência a aplicação do Direito). Um exemplo poderia ser ilustrativo: jamais poderia um juiz brasileiro deixar de dar efeito a um contrato particular de trust, constituído segundo o Direito inglês, pelo simples fato de o Direito brasileiro não contemplar restrições à propriedade real, além daquelas fixadas rigidamente na lei, como o usufruto, as servidões, e portanto, aparentemente não-autorizadas por disposições contratuais, tal o trust. Ora, a análise comparativa do trust mostra tratar-se de disposições legais ou contratuais, segundo as quais, uma pessoa, (settlor) nu-proprietário, institui outra (o trustee) como proprietário, para que administre os bens, em beneficio de um terceiro (o "cestui que trust", também denominado "beneficiary"), operação essa que se agrega de tal forma à propriedade em questão, que não-confere qualquer direito ao "trustee" de dispor da mesma. O que mostra o Direito Comparado é que o "trust" ${ }^{1}$ é um instituto nascido da "Equity" (veja-se além, sobre tal conceito), com a finalidade de proteger os relativamente incapazes ou desvalidos, como menores ou eventuais viúvas, pelo fato de pessoas partirem para guerras ou longas viagens e deixarem seus bens, sob a administração de terceiros, através de contratos fiduciários, que criavam ônus, ou seja obrigações de natureza real, de estes administrarem tais bens, móveis ou imóveis, em beneficio de outrem, conquanto a propriedade tenha sido passado àqueles terceiros. Em que pese a dificuldade de se considerarem fissuras no conceito

1. O "trustee", inicialmente centrado em pessoas fisicas, passou a ser constituído em nome e sob responsabilidade de empresas, que já tinham especialização em lidar com valores de outrem, os bancos comerciais; muitos bancos ingleses e norte-americanos indicam tais funções na sua própria denominação comercial. A acumulação de riqueza sob sua guarda e o grande poder que acabou por concentrar em suas atividades, determinou que se formassem verdadeiras entidades com enorme poder econômico, o que engendraria a que se passasse a denominar de "trust", os imponentes conglomerados financeiros e comerciais que dominam determinado setor da economia e, por antonomásia, a própria atividade de controle de setores do mercado. Assim, quando proibidas tais atividades, sua tipologia se verifica com as denominadas "leis antitrust" (Shermann-Clayton Acts dos EUA), ou seja, proibições de atividades monopolizantes ou dominadoras, numa economia capitalista e, quando incentivadas, como numa economia centralmente planificada, como a da antiga URSS, passavam a tipificar uma reunião de empresas diretamente controladas, destinadas à gerência e explotação de determinada atividade (a ex.: um truste que administraria a atividade das aciarias dos Urais, composto de empresas estatais dedicadas, cada qual, a carvão, ferro, transporte, transformação industrial e comercialização de produtos semi-finais), constituindo-se, assim, numa pessoa de direito interno, para fins de relações con terceiros e com o Estado. Relembre-se que o "trust", juntamente com a "firm" e o "kombinat", eram as pessoas jurídicas que realizavam contratos econômicos na antiga URSS. 
de propriedade pela via de contratos, a jurisprudência comparada, em particular nas ocasiões em que no Direito francês houve necessidade de darem-se efeitos a "trusts" mostra a possibilidade de, através de uma comparação de institutos, que se encontre um "trust" que cumpra as funções do desconhecido, seja, inclusive para combinar vários, de maneira que as finalidades daquele se cumpram.

2. Os Percalços do Comparativismo Jurídico.

Como nota preliminar, importa observar que "Direito Comparado" é, assim, uma expressão enganadora, no universo do direito-norma. Relembre-se que os únicos fenômenos normativos que existem entre sistemas jurídicos são aqueles oriundos do Direito Internacional Público (com todas as contaminações de "Internacional" que sofram os ramos dos direitos internos dos Estados, como Direito Penal Internacional, Direito Tributário Internacional, etc.), do Direito do Comércio Internacional ou do Direito Internacional Privado, este último, quando tem suas fontes internacionais.

Contudo, o Direito Comparado tem uma realidade como direitociência, uma vez que é possível realizar-se uma comparação de sistemas jurídicos de países diferentes, com metodologia científica, estabelecer princípios comuns e diferenciados, inclusive até mesmo uma teoria geral do comparativismo jurídico (à maneira de uma gramática universal de todas as línguas existentes). Isto posto, deve ficar esclarecido que, no Direito Comparado, o que se tem em mira é conhecer termos em comparação, na dupla tarefa de: $1^{\circ}$ conhecer cada termo, isoladamente, na sua individualidade e especificidade; $2^{\circ}$ neles distinguir elementos de presença comum e, a partir do descobrimento de valores comuns, realizar a comparação.

$\mathrm{Na}$ verdade, o direito, concebido como um sistema originário da cultura e da civilização de um povo, reflete seus valores, e sendo uma cultura de um povo ou da civilização de uma época, vale enquanto valem os valores inconfundíveis e irredutíveis daquelas cultura e civilização. Um paralelismo com as línguas vivas, que igualmente são fruto da cultura e da civilização de um povo, mostra que é totalmente improcedente dizer-se que a língua inglesa é melhor ou pior que a portuguesa, que esta é mais clara do que aquela ou que aquela é mais concisa do que 
esta: o que importa é que, tanto numa quanto noutra, as idéias são expressas com igual clareza e os valores são transmitidos de pessoa a pessoa. ${ }^{2}$

Se considerarmos o direito-norma como uma linguagem que se autoexplica e o direito-ciência como uma metalinguagem, isto é, uma linguagem que "fala" do direito-norma, poderemos melhor compreender os problemas da passagem de um sistema jurídico nacional para outro. O direito-norma tem, nos tempos atuais, necessariamente de ser expresso na língua do povo que o criou (e que o criou, ao usar a única língua que dela se utiliza no seu dia a dia, mas que, no entanto, na maioria das vezes, poderá ser igualmente uma língua de outros povos, como o português, o espanhol, o inglês, ou o francês, caso em que poderá haver significativas variações dentro do mesmo universo lingüístico). ${ }^{3}$ Contudo, o direitociência pode ser expresso em qualquer língua, inclusive naquela do povo que criou o objeto da análise, e, no caso de ser esta uma língua comum a outros povos, haverá necessidades de explicações das citadas variações lingüísticas, caso se explique, com a mesma língua, sistemas jurídicos nacionais de povos distintos, que falam o mesmo idioma! $!^{4} \mathrm{Na}$ verdade, o Direito Comparado vai além do campo da Lingüística; além de buscarem-se sinonímias ou traduções, buscam-se equivalências de significados, tanto numa tradução linear, quanto nos resultados de atribuição de sentido a palavras e criação de institutos complexos. ${ }^{5}$

Para uma leitura, em inglês, do direito norte-americano, conforme escrito por autores provenientes do sistema da Common Law daquele país, ' recomenda-se do prof. E. Allan Farnsworth An Introduction to the Legal System of

2. Tanto é concisa a língua portuguesa ao dizer: "plantando, dá" ("If one plants, one can get good crops"!) quanto o inglês que inventou a palavra "torts" (responsabilidade civil por danos extracontratuais!). Igualmente impróprio seria afirmar que o italiano é uma língua que se presta ao canto (pois, como então ficariam os "leader. de Schummann ou de Schubert, ou as serestas brasileiras!), ou que o alemão é uma língua clara (pois então não haveria como justificar a incrivel expansão do inglês no comércio internacional, onde a clareza é a qualidade primordial das relações negociais, entre pessoas que não falam a mesma lingua!).

3. Tal fato revela, portanto, que uma mesma língua pode ser o veículo de expressão de distintos sistemas juridicos nacionais, os quais, por utilizarem o mesmo meio de expressão, em absoluto podem autorizar a afirmação de similitudes de institutos juridicos.

4. É por tais motivos que, no estudo do Direito Comparado, são imprescindíveis as distinções entre português de Portugal e português do Brasil, ou entre inglês da Inglaterra e inglês dos EUA, do Canadá, da Austrália, da İndia, de Trinidad-Tobago ou da Jamaica!

5. Um exemplo que nos ocorre: empregador, em Portugal, é "patrão" e nos EUA é "employer". Seriam as mesmas realidades, do ponto de vista normativo, de cada sistema jurídico nacional? 
the United States, ${ }^{6}$ bem como a erudita obra do prof. Peter Hay, An Introduction to the United States Law. ${ }^{7}$ Para uma leitura do Direito norte-americano, utilizando-se como metalinguagem o francês, existem várias obras relevantes, das quais se destaca do prof. René David, a genial obra, Les Grands Systèmes de Droit Contemporain (Droit Comparé). O português é utilizado como metalinguagem na apresentação de outros sistemas (conquanto em segunda geração, porque tradução de outra língua) na primorosa tradução da referida obra do prof. René David, conforme empreendida pelo dr. Hermínio A. de Carvalho. ${ }^{8}$

Quando linguagem e metalinguagem se confundem na mesma exposição de idéias (os professores norte-americanos que explicam o direito norteamericano, em inglês), o empreendimento resulta em obra de grande precisão e desnecessidade de explicação de termos (pois prescinde-se das questões de tradução de uma língua para outra, uma vez que se trata de transformar uma linguagem técnica numa linguagem corrente, mais acessível, ou seja, tradução no sentido de explicitação). Neste particular, o comparativismo perde em muito, pois, se trata de continuar-se num mesmo sistema, tautologicamente descrevendo o mesmo fenômeno. Contudo, quando se tem de utilizar uma metalinguagem distinta daquela da língua explicada (leia-se: uma compreensão do mundo jurídico estrangeiro, a partir de uma visão de outro sistema distinto do analisado), há duas operações envolvidas, como no caso do presente trabalho: $1^{\circ}$ a explicitação na metalinguagem, o português do Brasil (e não de Portugal, porque se trata de linguagem técnica), dos institutos jurídicos norte-americanos e $2^{\circ}$ a explicitação em português (igualmente do Brasil) da exata ou aproximada correspondência dos institutos norte-americanos com os existentes no Direito brasileiro. Trata-se, assim, de duas traduções: a traduçãoexplicitação e a tradução-equivalência!

Para evitar que o presente estudo se torne uma enciclopédia repleta de rodapés explicativos das nuances dos termos, iremos usar e abusar de aspas e parênteses e dos itálicos. Inexiste, de nosso conhecimento, um dicionário confiável inglês-português de termos jurídicos. De nossa parte, utilizaremos o Black's Law

6. E. Allan Farnsworth, An Introduction to the Legal System of the United States, Parker School of Foreign and Comparative Law, Oceana Pub. Inc. Nova York, 1963.

7. Peter Hay, An Introduction to the United States Law, Amsterdam, Nova York, Oxford, North Holland Pub. Co., 1976.

8. René David, Os Grandes Sistemas do Direito Contemporâneo: Direito Comparado, Lisboa Editora Meridiano, Limitada, $2^{a}$ edição, 1978, tradução do dr. Hermínio A. de Carvalho. 
Dictionary ${ }^{9}$ e o Jowitt's Dictionary of English Law, ${ }^{10}$ recomendados, respectivamente para o Direito norte-americano e para a "Common Law" da Inglaterra, ambos inglês-inglês (portanto de tradução-explicitação).

3. Os Grandes Sistemas de Direito.

O Direito Comparado, como ciência de comparação dos sistemas jurídicos, agrupou os mesmos em grandes famílias, que têm variado segundo os autores, em função dos critérios adotados pela divisão dos mesmos.

Uma classificação bastante útil é a do professor René David, op. cit., que reuniu os subsistemas de direitos nacionais, nos seguintes sistemas ou famílias:

$1^{\circ}$ o sistema romano-germânico, que os autores do sistema da "Common Law" denominam "Civil Law" no qual se encontra o Direito brasileiro;

$2^{\circ}$ o sistema da "Common Law" que, conforme será esclarecido mais além, não deve ser confundido com "sistema inglês" (porque se aplica a vários países, embora nascido na Inglaterra), nem com "britânico" (adjetivo relativo a GrãBretanha, entidade política que inclui a Escócia, que pertence ao sistema da família romano-germânica), nem com anglo-saxão (porque este adjetivo designa o sistema dos direitos que regiam as tribos, antes da conquista normanda da Inglaterra, portanto, anterior à criação da "Common Law" naquele país);

$3^{\circ}$ o sistema dos direitos socialistas, na atualidade, que compunham a denominada Europa do Leste, capitaneados pela URSS, até a queda do Muro de Berlim e o esfacelamento daquela;

$4^{\circ}$ outras concepções da ordem social e do direito, tais como o direito muçulmano, indiano, direitos do Extremo Oriente, direito judaico, direitos da África e de Madagascar, que em determinados países é a principal fonte das normas jurídicas nacionais (Irã, Iraque) e em outros, relevantes para determinados ramos do direito privado, em particular, em matéria de família, sendo os demais campos, ora da família romano-germânica (Israel e Líbano) ora da "Common Law" (Índia, Paquistão).

9. Black's Law Dictionary, $4^{\mathrm{a}}$ edição, revista, Henry Campbell Black, St. Paul, Minn., West Pub. Co., 1968

10. Jowitt's Dictionary of English Law, The Late The Right Honourable The Earl Jowitt e Cifford Walsh, LL.M., 2a edição por John Burke, Barrister Sometime Editor of Current Law, Londres, Sweet \& Maxwell Limited, 1977. 
De tal classificação, no presente estudo, interessa o contraste entre o sistema romano-germânico e a "Conımon Law" dadas as peculiaridades de cada familia de direitos (que permite uma certa sistematização no Direito Comparado) e por serem as famílias mais relevantes da maioria dos sistema jurídicos nacionais da atualidade. Relembre-se que o Direito norte-americano, com exceção do Estado da Luisiana, é considerado como um direito da família da "Common Law" misto, ou seja, pertence àquela família, mas sintonizado muito perto da "Civil Law" (comparese com o direito da Escócia, considerado da "Civil Law" misto, ou seja parente do Direito brasileiro, mas muito perto da "Common Law").

\section{O Sistema Romano-Germânico.}

O lema de toda filosofia socrática, que constitui a base histórica da filosofia ocidental, era fundamentado em outro, que se inscrevia no frontispício dos principais templos gregos: gnoti sautón (conhece-te a ti mesmo). Na verdade, tal atitude é conducente a descobrir e questionar os próprios valores e realidades, antes que se pretenda iniciar uma indagação filosófica de quem ou do que está fora do sujeito cognoscente. Além de tal postura filosófica, o conhecimento da família dos direitos romano-germânica se faz imprescindível, igualmente, no presente estudo, sendo dado que o sistema jurídico norte-americano é considerado como um sistema misto entre esta e a "Common Law"

Tarefa desproporcional às finalidades do presente trabalho, pela sua complexidade e extensão, a descrição da família romano-germânica, que "brevitatis causa" denominaremos "Civil Law" (da mesma forma como fazem os autores ingleses e norte-americanos), será feita com um propósito deliberado: apontar os elementos que permitam comparação com a "Common Law" Na verdade, comparar, em Direito Comparado, deve ser uma atitude racional, determinada por critérios metodológicos (que, infelizmente, não teremos a oportunidade de desenvolver no presente estudo) de tal maneira que não se tenham dois quadros estanques, pintados por pintores diversos, mas se possa ver, nos dois quadros, a mesma mão do pintor, que é o homem em sociedade, que ao pintá-los deixou sua marca personalíssima em ambos, conquanto tenha feito obra totalmente distinta uma da outra.

Fato marcante na infância da família romano-germânica foi a compilação e codificação do Direito Romano, que cristalizou, em textos harmônicos, 
normas costumeiras, normas escritas esparsas, decisões jurisprudenciais e doutrinárias, juntamente com a obra dos glosadores que, aos poucos, foram em particular nas universidades medievais (que vicejavam à sombra dos mosteiros e conventos, portanto bem próximas dos cultores do Direito Canônico, na época, escrito e extremamente bem elaborado), dando uma feição racional às soluções casuísticas e assistemáticas dos jurisconsultos romanos. Na sua gênese, portanto, nota-se a preocupação com uma ordem racional de conceitos, aparecendo o direito como um sistema: um conjunto de preceitos que deveriam estar agrupados, tal qual um organismo vivo. Mesmo que se reconhecesse a máxima do Direito Romano de que "ex facto oritur jus", o direito foi concebido como uma criatura conceitual perfeita, um modelo de justiça racional a ser atingido, a estrutura basilar de uma sociedade ideal, à qual a sociedade real e existente deveria ser conduzida. Note-se que, mesmo que os fatos não correspondessem ao ideal do direito, este teria sua precedência sobre os fatos (e evidentemente que estamos descrevendo tendências, pois o sistema possuía instrumentos de moldar-se à realidade).

De tal postura, nascida do exame erudito dos autores considerados aceitos (vide a Lei das Citações do imperador Valentiniano, 426 d.C., que mandava aos juízes só considerarem como fonte de direito, as citações dos cinco jurisconsultos: Papiniano, Paulo, Gaio, Ulpiano e Modestino), com a consequiente fixação na forma de preceitos escritos, os brocardos, até a reunião, por eruditos, de normas esparsas, em códigos, ordenados pelos governantes (e são vários, ao lado da codificação do imperador Justiniano, os Rôles d'Oléron, as Siete Partidas...); perpassando pela autoridade dos reis ou outros poderes legiferantes, o sistema já marcava sua presença na história das civilizações: a preocupação com a lei escrita, onde deveria haver uma sistematização de princípios gerais, em detrimento de particularismos. Em tal universo geométrico, a dedução, também denominada "silogismo" foi o método exegético empregado, copiando dos estudos universitários medievais o rigor lógico de sua apresentação formal, até mesmo com o exagero de se dizer que a verdade é aquela que formalmente se conclui ou se infere por um raciocínio bem construído, de acordo com a Lógica Menor!

Nas universidade medievais, estudantes (futuros juízes, advogados e legisladores) e professores, antes estavam preocupados com a racionalidade e logicidade do sistema, do que com os reais efeitos da aplicação da norma jurídica (que era sempre uma proposição abstrata e geral) na vida corrente da sociedade. As construções silogísticas foram apuradas, e seus edifícios lógicos se tornaram de tal 
sofisticação $^{11}$ que seus processos mnemônicos fariam as atuais linguagens dos "softwares" hoje disponíveis, parecerem jogos infantis.

$O$ verdadeiro fantasma a ser evitado era e, de certa forma, continua sendo o casuísmo na lei. A certeza da existência e do conteúdo da norma que o direito escrito apresentava, bem como a busca das generalidades racionais que o conjunto normativo (códigos) representava, fizeram com que a "glosa judiciária" (jurisprudência casuística) fosse afastada, em favor da "glosa erudita" (a doutrina) e que tanto o costume geral, como o assim dito "costume judiciário" (a jurisprudência) fossem desprezados, em benefício da lei escrita (e sempre que possível, reunida em conjuntos harmônicos e racionais, os códigos).

Por mais que se queira atribuir um papel importante de fonte formal do direito à jurisprudência, o conceito corrente na "Common Law" de uma regra tipo "judge-made law" vai ter uma aceitação sujeita a críticas das mais ferozes por parte dos doutrinadores, na "Civil Law" sobretudo após a doutrina da separação dos poderes à la Montesquieu. Na verdade, Montesquieu adaptaria a teoria do inglês John Locke da separação dos poderes; para este, Executivo, Legislativo e Federativo (ou seja, muito mais preocupado com as relações de equilíbrio entre o Executivo e Legislativo, sendo o Poder Federativo aquele referente ao direito da representação exterior do Estado, de fazer a guerra, que deveria estar controlado pelo Legislativo) deveriam estar separados (o que já se verificava na Inglaterra do tempo, em certa medida e o que Locke preconizava, era uma separação declarada e fixada por princípios imutáveis); o importante era controlar o rei (e menos os juízes, que faziam a lei). Na teoria de Montesquieu, qualquer veleidade de dar-se aos juízes o poder de fazer a lei, seria ir contra o postulado da separação dos poderes. Reforça-se, assim, a concepção piramidal do direito no sistema romano-germânico: o Judiciário é um poder que tem atributos dos mais amplos, não sendo controlado por nenhum dos outros dois, mas não tem iniciativa e seu poder é limitado pela "res judicata"; generalizações a partir de casos julgados, só na matéria "sub judice" e sem qualquer possibilidade de criar precedentes, ou seja, de se imporem a casos semelhantes no futuro, pela sua própria efetividade.

11. Na aplicação da norma jurídica, havia a principal preocupação de armarem-se silogismos, com suas duas premissas, sendo uma universal (a lei) e outra particular (o fato), seguindo-se, automaticamente, a conclusão. O grande exercício nas Universidades do início do século XIII, era a construção dos caminhos lógicos (a denominada Lógica Menor), que consistiram em desenvolver as teorias aristotélicas sobre o conhecimento científico, até os limites lógicos possíveis! 
Com a formação dos Estados modernos, onde a figura do legislador leigo e centralizador da função de elaborar o direito, o sistema dos direitos romanogermânicos ganha sua feição atual, com temperamentos de considerar-se como legislador, não mais o rei, mas o povo. De qualquer forma, o Judiciário é unificado, seja no Estado absolutista, seja no Estado democrático, nas funções personalizadas em figuras leigas, funcionários do Estado; não se admitem jurisdições eclesiásticas (que se recolhem a assuntos de direito canônico, restritos "ratione personae" e "ratione materiae" cada vez mais circunscritas ao pessoal eclesiástico, em matéria de consciência moral e religiosa), uma vez que a jurisdição é civil, e as jurisdições estamentais passam a se configurar como jurisdições permitidas, da mesma maneira que se permite a liberdade contratual (a arbitragem comercial se transforma em soluções negociais entre as partes e perde seu caráter de obrigatoriedade e de força coativa, ao lado das soluções judiciárias típicas).

O pensador que melhor caracteriza o sistema romano-germânico é Hans Kelsen: o direito é uma construção escalonada (Stufenbau), tão-racional e geométrica, que por isso mesmo, tem a forma de uma pirâmide, no ápice da qual se encontra uma norma fundamental (Grundnorm), a partir da qual, as normas menos gerais, retiram sua eficácia, e vão perdendo sua generalidade, até aquelas normas colocadas na base, (os contratos e as sentenças) onde o princípio geral tem sua eficácia, após percorrer outros campos de particularismos crescentes (a constituição, a lei ordinária, o artigo...).

Os perigos em tal tipo de sistema se referem ao culto desmesurado à lógica formal e à racionalidade da construção dedutiva, tida como válida por seu próprio rigor arquitetural, por ela mesma válida, porque racional e coerente dentro do raciocínio abstrato, mas com um acentuado desprezo pelos resultados, na vida corrente. Efetividade no sentido da atuação da norma na realidade do dia-a-dia é preocupação de certa maneira secundária. Exemplo típico é a própria filosofia que preside certas posturas: a preocupação de definir a tipologia dos ilícitos, em função da gravidade abstrata do dano à sociedade (e menos, em definir os tipos, a partir dos remédios; compare-se o Direito Criminal da "Common Law" ou mesmo os tipos da responsabilidade civil por danos criminais ou não-criminais, os torts, que são definidos a partir dos resultados que se pretende, ou seja, dos remédios buscados).

Contudo, se há tais perigos, há suas soluções. A eqüidade, aquela virtude de temperar o rigor da lei, que força tanto o legislador quanto o juiz a lembrar-se que o direito é uma construção que tem sua validade, na medida em que 
realiza os valores transcendentais da justiça (o "suum cuique tribuere"), frontalmente proíbe que se satisfaça o disposto na lei, se houver ofensa à idéia magna da realização da justiça. Por outro lado, conforme se caminha nas complexidades do direito moderno, há outras maneiras de temperar o distanciamento do sistema da realidade dos fatos, como provam, no Brasil, a exemplo, a emergência das súmulas e da possibilidade de recursos para harmonizar a jurisprudência do mesmo tribunal ou de tribunais inferiores. Nenhum advogado praticante irá negar a importância de um arquivo de jurisprudência dominante nos vários assuntos de seu interesse e qualquer estudante sabe da importância do conhecimento da jurisprudência como um dos mais poderosos instrumentos na aplicação do Direito. Outra prova é a aceitação generalizada de compilações de jurisprudência uniforme em certas matérias tópicas, conforme as publicações que se tornam cada vez mais freqüentes entre nós; e quando se fala em Informática no Direito ou em Informática Jurídica, a primeira indagação é de saber quando serão aquelas engenhocas inteligentes aplicáveis para melhor conhecer-se a jurisprudência e dela extrair maior aproximação com a realidade dos fatos correntes!

De qualquer forma, o casuísmo (doença da casuística) é o grande mal que o sistema romano-germânico teme, de tal forma, que mesmo a higidez do estudo de casos é, de certa forma, evitado, ou pelo menos, olhado com suspeição de vir a causar caos no edifício geométrico e piramidal.

\section{Os sentidos da expressão "Common Law"}

É interessante observar como, por vezcs, o objeto analisado influi na escolha da metodologia da análise. Esta, que pretendemos fazer, deverià, ápós os esclarecimentos iniciais, começar por definir "família de direitos" ou "família de sistemas jurídicos". numa das quais, se situa a "Common Law" em comparação com o sistema brasileiro. Assim deveria proceder um analista formado na tradição romanística, de conceber o Direito como um sistema racionalmente coerente $\mathrm{c}$ bem ordenado, a partir de conceitos gerais, ideais e típicos (muitas vezes tão-abstratos que refogem à sua praticidade), em direção a particularidades. Antecipando conceitos que serão avançados mais além, diremos que a "Common Law" constitui uma "família de direitos" à qual pertence a maioria dos direitos dos Estados da Federação norte-americana, em contraste com a "família dos direitos romano- 
germânicos" à qual se filia o Direito brasileiro. Contudo, daremos preferência a um enfoque na formação histórica da "Common Law" de raízes profundamente pragmáticas e despregadas de qualquer compromisso com modelos abstratos (comparativamente à tendência da família dos direitos romano-germânicos) e influenciados pelo método indutivo, começaremos pelo particular. Em tal tarefa, para melhor estudar os sentidos da expressão "Common Law", faremos referência a conceitos em relação aos quais existe um outro, cujo contraste permite uma explicitação dos significados daquele.

\section{1. "Common Law" e "Equity Law"}

A primeira acepção de "Common Law" é de "direito comum" ou seja, aquele nascido das sentenças judiciais dos Tribunais de Westminster, cortes essas constituídas pelo Rei e a ela subordinadas diretamente, e que acabaria por suplantar os direitos costumeiros e particulares de cada tribo dos primitivos povos da Inglaterra (este, portanto, antes da conquista normanda em 1066, denominado direito anglo-saxônico), ${ }^{12}$ enquanto oposta a Equity, direito aplicado pelos Tribunais do Chanceler do Rei, originado de uma necessidade de temperar o rigor daquele sistema e de atender a questões de equiidade.

Após a conquista normanda da Inglaterra, o direito que os Tribunais de Westminster criavam, era denominado "Common Law" (corruptela da expressão dita na língua do Rei: "commune ley") em oposição aos direitos costumeiros e locais dos primitivos habitantes, aplicados pelas "County Courts", e que logo seriam suplantados. A distribuição da justiça era considerada como uma prerrogativa real, que os reis outorgavam a funcionários, os "judges". que perambulavam pelo reino (a idéia de "circuit" que permanece na denominação de alguns tribunais nos EUA e da Inglaterra, como circunscrição delimitativa de jurisdição de um tribunal), na sua tarefa de representar o Rei. À semelhança dos "praetores" do Direito Romano da época formular, ouviam as queixas e davam (ou antes, "vendiam" no sentido de pagamento por um serviço público, de custas processuais) um wril, que era uma ação

12. Portanto, haveria, na História da "Common Law". uma primeira oposição de conceitos: "Common Lany" versus direito anglo-saxônico, este, constituido de direitos locais, tribais e costumeiros, e que somente deixaram alguns traços para direitos locais ingleses, mas que pouco influenciaria a "Common Lav". que se formou a partir do "jus scriptum" e jurisprudencial posterior a conquista normanda. 
nominada e com fórmulas fixadas pelos costumes, que correspondia à obtenção de um remédio adequado à situação. A idéia do writ era de que se constituía numa ordem dada pelo Rei às autoridades, a fim de respeitarem, em relação ao beneficiado que obtinha o remédio, sua situação jurídica, definida pelo julgamento a seu favor. Se não houvesse um writ determinado para a situação, não haveria possibilidade de dizer-se o direito (e, sendo assim, criava-se uma intolerável denegação da justiça e a impossibilidade de saber-se qual o direito aplicável). Concedido o writ, posteriormente, um "jury" composto de leigos, em certos casos, julgaria as pretensões da pessoa beneficiada pelo writ (à semelhança do "judex" no processo formular romano), em razão de determinar os fatos, em função da norma predeterminada; a decisão dos "jurors" era denominada "finding" ${ }^{13}$

René David acentua que, enquanto os juristas da Europa continental da época, esforçavam-se por determinar as regras do direito material (as regras de fundo), na Inglaterra, a evolução era no sentido de elaborar as regras quanto às possibilidades de obterem-se as ações processuais; obtidas essas, quanto ao julgamento sobre o direito contestado, não havia a menor previsão ou a menor preocupação. Na expressão da época: "remedies precede rights" (os remédios têm precedência aos direitos subjetivos). O sistema era sem dúvida pesado, a ver-se pelo fato de que dos 56 writs existentes em 1227, seu número somente em 1832, será elevado para 72, data em que o sistema seria profundamente reformado ( op cit. pp. 333 e 336, nota de rodapé n. 9); contudo, por analogia, para determinadas circunstâncias, concediam-se wrițs para situações novas. A exemplo: inexistia um writ determinado para os contratos; contudo, através de um writ of detinue originariamente destinado a beneficiar um possuidor de boa-fé, seria possível proteger quem detivesse sem justo título uma propriedade, portanto, quem detivesse a coisa sem ter um contrato que legitimasse a posse; ou ainda o writ of trespass, que originalmente servia para proteger um dano causado por um ato ilícito, seria aplicado, analogicamente, para proteger um contratante que tivesse sido prejudicado pela inadimplência. Note-se, sobremaneira, que não havia maneira de fazer cumprirse compulsoriamente o contrato: inadimplido, partia-se para perdas e danos. Assim

13. "Finding", substantivo derivado do verbo "to find" (descobrir, achar) significa, na atualidade, em particular no plural, "what has been learnt as the result of inquiry", portanto, "resultados de uma investigação" "The findings of the Commission": "What is determined by a jury" (A.S. Hornby Oxford Advanced Dictionary of Current English, 1974, verbete: find (2). Nos EUA, é sinônimo de verdict, o resultado da deliberação do Petty Jury, em casos criminais. 
sendo, numa locação predial, na inadimplência dos alugueres, a possibilidade de cobrança de alugueres vencidos, ou a manutenção do contrato (observe-se a vis attractiva dos direitos reais imobiliários, que chegavam a ofuscar as relações baseadas em contratos sobre imóveis, fazendo-os regulados pelos princípios dos direitos reais, em particular pela regra do "locus rei sitae", inclusive para ações de família que sobre eles versassem; vide, igualmente, a moderna qualificação do Direito norte-americano de considerar o estado civil das pessoas sendo "res" em parte pelas implicações patrimoniais do casamento).

É bem evidente que tal sistema, formalístico e rígido, logo deveria sofrer radicais modificações, premido pelos fatos das patentes injustiças; os recursos ao Rei, fora das regras processuais da "Common Law", aos poucos, se tornam possíveis, sendo que o Rei os decidia, em matéria de consciência e não mais por motivos estritamente jurídicos. Um eclesiástico (ao tempo em que ainda não existia a Reforma Anglicana, portanto católico e altamente influenciado pelo Direito Canônico da época), o confessor do Rei, o Chanceler, cognominado "the keeper of the king's conscience" passaria a conceder certas medidas que, aos poucos, foram-se estendendo, não mais em matéria de recursos de decisões, mas em matéria de conhecimento originário das causas. A frequêencia de tais procedimentos excepcionais, sempre concedidos quando não houvesse um writ da "Common Law" fez com que se firmasse a prática de uma verdadeira justiça paralela às Courts of Westminster, com uma linguagem própria, seus precedentes próprios, e que acabariam por ser aplicados pelos tribunais do Chanceler: Courts of Chancery, que rivalizavam com as Courts of Westminster, tribunais aqueles que acabaram por formar um corpo de normas, a "Equity". Na verdade, as "Courts of Chancery" apoiavam-se nas normas do direito canônico, bem mais evoluídas e racionais que o casuísmo dos procedimentos da "Common Law". Por várias razões históricas, a "Equity" teve um desenvolvimento portentoso, em particular, naqueles períodos em que o Rei, por questões de guerras internas (a ex.: a Guerra das Duas Rosas) se encontrava na impossibilidade de reunir seu Conselho e julgar os recursos em matéria de "Common Law" ganhando assim relevância a figura do Chanceler e de sua justiça. Com a Reforma Anglicana de Henrique VIII (e relembre-se a aguda oposição entre este e seu Chanceler, Thomas Moore, ou em latim, Morus, posteriormente santificado pela Igreja Católica), o Chanceler passaria a ser um cargo ocupado não mais por um eclesiástico. Conquanto na época a "Equity" já se encontrasse afastada do direito canônico e em ritmo de desenvolver suas regras 
próprias, já se encontrava contaminada pelo mesmo formalismo da "Common Law" sendo ambos os sistemas dominados pela regra do "stare decisis" ${ }^{14}$ (coisa julgada), ou seja, de que o direito é expresso pela atuação do juiz (judge-made law), conforme será oportunamente estudado. Finalmente, os "Judicature Acts" de 1873 e 1875 suprimiram as "Courts of Chancery" passando a competência de aplicação, tanto da "Common Law" quanto da "Equity", a tribunais comuns na Inglaterra.

Mesmo unificados os órgãos de aplicação da "Common Law" e da "Equity" conservaram eles suas características originais e suas regras próprias; o princípio, que sempre foi dominante e que, em certa medida continua, tanto na Inglaterra como nos EUA, é de que a utilização da "Equity" só é possível, em quanto inexistir remédio na "Common Law"; na atualidade, tal princípio nem tanto quer significar a aplicação da "Common Lcow" ou da "Equity" em função do remédio pretendido, mas muito mais pela classificação do instituto jurídico neste ou naquele direito. $^{15}$

Assim, hoje, na Inglaterra, pertencem ao domínio da "Common Law" as seguintes matérias: o direito criminal, todo o direito dos contratos (originalmente originário na "Equity") e o da responsabilidade civil ("torts"), nos quais se especializaram os "Common Lawyers" e no qual a atuação do "jury" é de sua essência. Ao domínio da "Equity" pertencem as matérias relacionadas aos direitos da "real property", ${ }^{16}$ dos trusts (contratos fiduciários, pelos quais o settlor transfere uma propriedade móvel ou imóvel, já vimos, a alguém, o trustee, para que a administre em favor de um beneficiário, o cestui que trust) das sociedades comerciais, das falências ("bankruptcy"), das questões de interpretações de testamentos e da liquidação de heranças. ${ }^{17}$ Embora na Inglaterra permaneça um

14. "Stare decisis" (pronuncia-se "stare diçáicis") é o que sobrou da expressão latina: "stare decisis et quieta non movere". ao pé da letra: "que as coisas permaneçam firmes e imodificadas, em razão das decisões"

15. A comparação entre a "Commın Law" e a "Equity" parece-nos assimilável, com grandes reservas, às peculiaridades da Justiça Comum e da Justiça do Trabalho, no Brasil. Ressalte-se, contudo, que a "Equity" tinha um campo de atuação em todos os ramos do direito, e que as Courts of Chancery tinham uma jurisdição aberta para qualquer tipo de pessoa, independentemente de as relações entre autor e réu serem relações de trabalho

16. "Real" (pronuncia-se "rial"), no sentido de "property of land. any natural resources, and buildings, contrasted with personal estate". Hornby, verbete: real estate portanto: propriedade imobiliária.

17. As matérias de interpretações de testamentos e de liquidação de heranças, nos EUA, são da competência de cortes especializadas ("Courts of limited jurisdiction"), em alguns Estados, como Nova York (Probate Courts e Surrogate's Courts). 
contraste entre "Common Lawyers" e "Equity Lawyers" mais pelo estilo de atuação e particularidade de problemas, a unificação dos órgãos judiciários permite hoje afirmar que a diferença entre "Common Law" e "Equity" se prende mais às tipicidades dos institutos abrigados em um ou outro ramo do direito, submetidos a interpretações judiciárias próprias (os "precedents" da "Common Law" e os da "Equity" em princípio, não são intercambiáveis, posto que marcados cada qual com um traço de sensibilidade própria aos problemas a serem resolvidos). Uma ilustração interessante de como funciona a "Equity" pode ser dada pela emergência da denominada doutrina da "piercing the corporate veil" (desconsideração da personalidade jurídica), para ter-se acesso aos bens dos sócios e evitar a fraude a credores, num procedimento falimentar, em particular, na obtenção de uma concordata; segundo a teoria da "Equity", das "clean hands" (quem vem solicitar um benefício ao juiz, deve vir de mãos limpas, ou em outras palavras, quem solicita uma concordata judicial deve estar de boa-fé) é permitido desconsiderar-se a personalidade jurídica e trazer os bens dos sócios para o patrimônio em discussão (e não a mera colação de bens da sociedade), na medida em que se prove, sim, ter havido fraude aos credores.

Os EUA receberam a "Equity" no momento histórico em que as oposições "Common Law" v. "Equity" já se encontravam esmaecidas. Nos EUA inexistem "Common Lawyers" e "Equity Lawyers" e, a partir da última unificação, em 1938 (na justiça federal), na atualidade, as "actions at law" e os "suits in Equity" se encontram reunidos no que se denomina as "civil actions"

Embora unificados na "civil action", os procedimentos contrastantes de "Common Law" e da "Equity" guardam nos EUA importantes traços diferenciadores. Nos procedimentos "triable at law" nos quais se buscam "Common Law reliefs" é possível, como regra, o julgamento, nos processos civis e criminais, pelo "jury"; o processo é inflexível, sendo que os remédios oferecidos resultam sempre numa indenização em dinheiro (award of money damages). Já nos procedimentos "triable in Equity" os "Equity reliefs" se traduzem em operações contra a pessoa do réu, não mais condenações em dinheiro, mas em injunctions, ordens judiciais de fazer ou deixar de fazer ("specific performance") multas compensatórias ou prisão, sob sanção por desrespeito a uma ordem judicial ("contempt of court"); verifica-se a ausência do "jury", bem como maior alargamento dos julgamentos em recurso ("wider scope of review on appeal"). Em geral, as questões disputadas que pertencem à eqüidade ("equitable issues") são julgadas pelo 
juiz togado e as questões que pertencem à "Common Law" ("legal issues") são julgadas pelo júri; nos conflitos para determinar-se se uma questão ("issue") é de "Equity" ou da "Common Law", resolve-se como um "equitable issue". ou seja, pelo juiz, sem a participação de um júri.

É interessante observar que alguns Estados da federação norteamericana ainda conservam tribunais unicamente dedicados aos julgamentos em "Equity" Montana tem mesmo uma codificação da "Equity Maxims", no seu Revised Code, "Chapter 49". Curiosa esta codificação, porque a característica fundamental que distingue a família dos direitos do sistema da "Common Law", face à família romano-germânica, é exatamente a resistência à codificação ("statutory law") e, a nosso ver, entre as normas da "Equity" e da "Common Law", estas últimas talvez fossem as que mais se prestariam à transformação em direito escrito, dado seu maior formalismo!

\section{2. "Common Law" e "Statute Law"}

O segundo sentido de "Common Law" se refere ao contraste existente entre, de um lado, a "Common Law". o direito criado pelo juiz (judge-made law) e, de outro, o direito criado pelo legislador postado fora do Poder Judiciário (Statute Law). Portanto, neste segundo sentido, de "judge-made law", "Common Law" opõese a "Statute Law" entendido este direito como aquele resultante dos "enactements of legislature" (tratados internacionais, Constituição Federal, constituições estaduais, leis ordinárias federais e estaduais, regulamentos administrativos federais, estaduais e locais, leia-se: municipais, inclusive os diplomas legislativos elaborados pelo Poder Judiciário, como o Code of Civil Procedure, elaborado pela Corte Suprema dos EUA). Em poucas palavras, na segunda acepção da palavra "Common Law" deve-se entender como o direito "laid down by the courts, rather than by legislature" O contraste é igualmente expresso com os conceitos: "case law" versus "Statute Law", entendendo-se como "case" o precedente judiciário, o "judge-made law" ${ }^{18} \mathrm{O}$ "case law" não se confunde com o decisional law, que, embora possa ter a metodologia do estudo e aplicação dos precedentes, em analogia com os julgados

18. "Case" aparece nas expressões "casebooks" (manuais para os estudantes em que se concentram, na maioria das vezes, os julgados, com algumas indicações de alguns "statutes"); "case method" (metodologia da descoberta e revelação do direito, através do exame dos precedentes judiciários), "case study" (id.). 
pelo Judiciário, refere-se às decisões em matéria contenciosa pelos tribunais ou órgãos judicantes do Executivo ("administrative courts" no sentido de "justiça de órgão quase-judiciário do Executivo" e não no sentido de "justiça administrativa" como o "Conseil d'État" francês, órgão judiciário especializado na aplicação do Direito Administrativo, que, ademais, inexiste no Direito dos EUA, da Inglaterra ou do Brasil). É igualmente necessária prudência na tradução da palavra "legislador" do sistema jurídico brasileiro (menos que suas correlatas como "legislativo", "legislatura"); "legislator" é, no sistema da "Common Law", tanto os órgãos do Poder Judiciário, quanto os do Legislativo e do Executivo! A oposição que se pretende dar entre a típica atividade do Judiciário naquele sistema e os outros órgãos legiferantes, deve ser "case" versus "statute" como nas expressões: "uma solução dada por um 'case', outra por um 'statute'; um 'case relief' ou um 'statutory relief"' (remédios previstos na jurisprudência ou na lei escrita).

Outro esclarecimento preliminar é de que a palavra usual para designar o lugar e a atividade do Poder Judiciário é court, que designa tanto o juiz singular de $1^{\circ}$ grau ("original court") quanto aqueles de $2^{\circ}$ ou $3^{\circ}$ graus, os nossos tribunais ("appellate courts"). A palavra "tribunal" (pronuncia-se "traibiunal") é reservada para designar, usualmente, o árbitro ou o colégio arbitral ("arbitral tribunal"). Vara se traduz, em geral por "division" e turma por "panel" ou por "bench", nos EUA; tribunal pleno é "full court" ou "en bench" ou ainda "en banc"; foro é "venue" (pronuncia-se "veniú").

Embora seja o "case law" a principal fonte do direito, pode ele ser modificado pela lei escrita, que, nos EUA, lhe é hierarquicamente superior; diz-se então que um "case" foi "reversed by statute".

É inexato dizer-se que na "Common Law" os juízes não aplicam um "Statute Law" enquanto não houver um "case" no qual seja o mesmo decidido. A questão é de método: enquanto no nosso sistema a primeira leitura do advogado e do juiz é a lei escrita e, subsidiariamente a jurisprudência, na "Common Law" o caminho é inverso: primeiro os "cases" e, a partir da constatação de uma lacuna, vaise à lei escrita. Na verdade, tal atitude reflete a mentalidade que o "case law" é a regra e o "statute" é o direito de exceção, portanto integrativo. Neste particular, a diferença entre o Direito inglês e o norte-americano é fundamental: a Inglaterra, que consideramos uma "Common Law" mais pura, desconhece a primazia de uma constituição escrita e que se coloca numa organização jurídica piramidal (à la "Civil Law"), nem tem idéia da primazia dos "statutes" tais as constituições estaduais do 
sistema federativo norte-americano, igualmente direito escrito, constituições estaduais essas que se colocam no ápice da lei estadual, que nos EUA é a maioria das disposições normativas. Na verdade, nos EUA, os precedentes judiciários segundo os "case law" dos Estados são a regra, e as decisões baseadas na lei federal são aquelas intersticiais, mas fique desde já anotado que nos EUA (por se tratar de um sistema misto entre a "Common Law" e "Civil Law") permanece o traço característico do sistema: o "judge-made law" Por outro lado, é necessário considerar-se o crescente intervencionismo do Estado na vida da sociedade: a implantação do "Welfare State" tanto nos EUA quanto na Inglaterra, tem trazido alterações no sistema; na verdade, uma "Common Law" pura seria aquela existente na Inglaterra ao tempo da Rainha Victoria, anterior à Revolução Industrial. Enfim, no caso da Inglaterra, é mister ter presente sua ativa participação na Comunidade Européia, onde existe um direito escrito elaborado por legisladores supranacionais, e que por decisões reiteradas da Corte da Comunidade Européia, tem vigência imediata na ordem jurídica interna, revertendo-se as prioridades que os intérpretes e aplicadores ingleses do direito local, tradicionalmente, praticam.

Outra preliminar a considerar é de saber se o juiz cria ou revela o direito preexistente. $\mathrm{Na}$ "Civil Law" a discussão tem sua importância, dada a concepção atualmente vigente da separação dos Poderes, na maioria dos países da família dos direitos romano-germânicos. Na "Common Law" o assunto também foi ventilado, mas hoje prevalece a teoria de que o juiz verdadeiramente cria o direito (razão pela qual apontamos, anteriormente, a prudência na utilização do termo "legislador" quando se estuda a "Common Law"!).

Nos EUA, como na Inglaterra (e diga-se, nos demais direitos pertencentes à família da "Common $L a w ")$, o ponto fulcral do sistema é a denominada "doctrine of stare decisis" também chamada "doctrine of precedents". Diga-se que a melhor tradução para "doctrine". no presente contexto, seria "regra" e portanto "doctrine of precedents" seria, em português: "regra do precedente" Precedent é a única ou várias decisões de um "appellate court", órgão coletivo de segundo grau que obriga sempre o mesmo tribunal ou os juízes que lhe são subordinados. Nos EUA, como veremos a seu tempo, a organização federal e a independência dos Estados federados (e se fala em State sovereignty, soberania dos Estados-membros) vêm trazer algumas complicações no que se refere à jurisdição, permanecendo, contudo, a norma de que são obrigatórios os precedentes conforme julgados pelos tribunais superiores (devendo notar-se que os julgados das "inferior 
courts of original jurisdiction" ou seja, dos órgãos de primeiro grau, não constituem "precedents").

Uma decisão que se tenha constituído em regra importante, em torno do qual outras decisões gravitam (com especificações, exceções interpretativas, extensões de aplicação) se denomina um "leading case", que passa a ser determinante para o estudante e o advogado, como primeiro "approach" na solução de uma questão prática. Sendo assim, em matéria de torts o "leading case" é Babcock v. Jackson; em matéria de direito constitucional da competência revisional da Corte Suprema sobre a legislação estadual, o "leading case" é Marbury v. Madison; em matéria de competência para decretação de divórcio, há dois casos Williams v. North Carolina (I) e Williams v. North Carolina (II), que estudantes e advogados já citam como Williams-I e Williams-II.

Uma "judicial decision" (sentença, ou, como no caso de criação de precedente: acórdão, embora exista a expressão "judgement-in-error" para designar uma decisão em grau de recurso) tanto na Inglaterra, quanto nos EUA, tem uma dupla função:

$1^{\mathrm{a}}$ decide o caso "sub judice" e faz coisa julgada ("res judicata" é expressão corrente nos EUA) dizendo os doutrinadores dos EUA, que assim se cria o direito, como o legislador, porém limitado às questões em controvérsia ("issues") e às partes; neste particular, nada de diferente existe quanto ao sistema romanogermânico, salvo no que diz respeito ao poder de "criação" de direito por parte do juiz;

$2^{\mathrm{a}}$ tem um efeito além das partes ou da questão resolvida (e aqui reside a tipicidade da "Common Law"), pois cria o precedente, com força obrigatória para casos futuros. $\mathrm{Na}$ verdade, o precedente não é uma regra abstrata, mas uma regra intimamente ligada aos fatos que lhe deram origem, razão pela qual o conhecimento das razões da decisão é imprescindível (não se pode aplicar um precedente fixado em matéria de motivos para divórcio, por exemplo, à resolução de uma questão que verse sobre contratos ou obrigações alimentícias).

O professor E. Allan Farnsworth aponta as razões da vitalidade da "Common Law" nos EUA, que, no fundo, são as qualidades do sistema: $1^{\text {a }}$ "equality" (possibilidade de que, em futuros casos iguais ou semelhantes aos julgados, a solução tenderá a ser a mesma); $2^{\text {a } ~ " p r e d i c t a b i l i t y " ~(v i r t u a l i d a d e ~ d e ~ q u e ~}$ futuros casos com elementos factuais semelhantes aos julgados, serão julgados da mesma maneira, o que permite ao advogado, em particular o consultor, melhor 
aconselhamento de seus clientes na prevenção de futuros pleitos); $3^{\mathbf{a}}$ "economy" (o que denominamos economia processual, uma vez que já há "issues" decididos, as matérias novas serão resolvidas com mais rapidez); 4 a "respect" (soluções que dão grande responsabilidade, pela sua força suasória, ao próprio Poder Judiciário).

Mister se faz explicar, ainda que por alto, como funciona a "doctrine of precedents" tendo-se, contudo, em mente, como adverte o referido prof. Farnsworth, que o sistema é altamente sofisticado e prático, e, sobretudo, como diz aquele professor, que não se aprende a andar de bicicleta com a leitura de um manual sobre mecânica!

$\mathrm{Na}$ verdade, explicar-se a aplicação de uma norma geral a um caso particular, como no sistema do Direito brasileiro (partir do geral ao particular) é bem mais fácil do que explicar a metodologia de partir de vários casos particulares para outros particulares, através de generalizações parciais, sem sair do contexto! A experiência pessoal mostra que, para alguém formado no sistema da "Civil Law", os primeiros passos na metodologia dos "cases law" é embaraçosa, com a impressão de caminhar-se num campo caótico; no entanto, na medida em que se vai familiarizando com o sistema, ele se torna interessante e instigante. Na verdade, para o estudante, é muito difícil, mesmo no nosso sistema, entender, pela pura teoria, as várias colorações conceituais da linguagem jurídica, que mostram as sofisticações dos institutos jurídicos; contudo, se alguém já tiver trabalhado em um caso prático, se tiver vivenciado uma questão igual ou assimilável à que tem de ser resolvida, o caminho é, certamente, mais fácil. Esta a vantagem dos precedentes: um arquivo da micro-história das relações conflituais humanas, com as soluções que tal microhistória apresentou: um formulário já pronto que se preenche com modificações factuais; a dificuldade maior é, portanto, saber se existe tal formulário e onde encontrá-lo!

A autoridade (authority), ou melhor dito, a força de impor-se a futuros casos dos "case law", segundo a doutrina, pode ser dividida em duas classes: a. persuasive, em geral de decisões de cortes de jurisdição paralela (mesma jurisdição de outros Estados), ou de votos vencidos ou minoritários da mesma Corte ou de cortes superiores, e a determinados assuntos (p. ex.: as cortes de Dellaware, especializadas em "corporations" e direitos de arena, ou as de Nova York, especializadas em comércio exterior), quando invocadas em outros Estados; b. binding authorithy, as decisões das cortes superiores de mesma jurisdição, ou as decisões da mesma Corte; repita-se que uma única decisão pode constituir-se em 
"precedent" (portanto, em oposição ao nosso sistema, onde, pelo menos, para considerar-se jurisprudência firme, em geral, se exige um número razoável de decisões no mesmo sentido).

Nas decisions que criam precedentes, na "Common Law" dos EUA, é necessário distinguir o que é um "holding" (na Inglaterra: "ratio decidendi") de um "dictum" (proveniente da expressão "obiter dictum"). Holding é o que foi discutido e argüido perante o juiz e para cuja solução, foi necessário "fazer" (criar/descobrir) a norma jurídica; reafirme-se, assim, a importância do conhecimento dos "facts of a case" aos quais a norma jurídica está ligada; dictum é tudo que se afirma na "decision" mas que não é decisivo para o deslinde da questão e, embora seja meramente "persuasive" tem importância suasória para as cortes subordinadas e para o advogado no aconselhamento de seus clientes.

Nos casos novos, apresentados na lacuna de "case laws". ou a corte pode reler os "holdings" anteriores com um espírito de interpretação restritiva ("to narrow the holding"), ou de uma interpretação extensiva ("to read a holding more broadly"), ou, ainda, meramente declarativa (na afirmação de que o caso se aplica à espécie, tal qual). Evidentemente que em tais operações, a mais comum é a técnica do "distinguo" e que permite transformar o que era "holding" em "dictum" e viceversa. Podem as cortes superiores, igualmente, desconsiderar um "precedent" e decidir com novas razões um caso semelhante: é o overruling (autêntica abrogação do precedente, ou, no que é mais comum, sua derrogação, continuando válido para certos aspectos da questão examinada o que nada mais é do que transformar um "holding" num "dictum"!).

De qualquer maneira, é necessário acrescentar que, entre "to follow a precedent", estabelecendo distinções até o limite de uma racionalidade ou, simplesmente "to overrule a precedent". as cortes dos EUA preferem "to honor the doctrine of precedent by careful distinguishing rather by outright overruling of objectionable decisions" (Farnsworth, id.).

Como já se afirmou, o "Statute Law" nos EUA tem uma posição de criação do direito muito mais vinculante do que na Inglaterra, reafirme-se, pela presença marcante de uma norma fundamental, a Constituição dos EUA, escrita e rígida, com vigência por cima de quaisquer outras normas escritas federais ou estaduais. Não-só a Constituição dos EUA, que foi redigida em 1788 (!), e as constituições dos Estados, bem como as leis infraconstitucionais, federais ou estaduais nos EUA, se apresentam de maneira totalmente diferente daquelas dos 
países dos sistema romano-germânico: em geral têm considerandos extensíssimos, redigem-se com artigos ("sections") quilométricos, onde, num único período, se escrevem as regras, as exceções, as enumerações e as interpretações particulares para cada assunto particularizado; a matéria, que na técnica conhecida das leis escritas da família dos direitos romano-germânica, se desdobra em incisos, alíneas, ítens, aberturas de parágrafos ou novos artigos, nas leis norte-americanas, são um único período, com centenas de vírgulas, inúmeras orações intercaladas e contrareferências a outros artigos da mesma lei.

A primeira observação quanto ao "Statute Law". é ser ele suscetível de ser constituído por um sistema piramidal (o que não se verifica nos "case laws" onde, uma vez fixado o precedente, tem ele seu valor dentro do sistema judiciário no qual foi concebido, sem que se possa dizer de hierarquia entre os mesmos, mas de conflitos de competência); portanto, nos EUA, em muito pouco diferindo quanto ao "jus scriptum" da família dos direitos romano-germânicos; e mais ainda, num sistema federal, que para o estudioso brasileiro, apresenta ainda menores diferenças (do que, por exemplo, para alguém que vive num sistema não-federativo) em relação ao próprio sistema jurídico. Na verdade, a hierarquia constitucional nos EUA é determinada não-só pelas próprias normas da Constituição Federal, como também pelos "case laws" sendo que emergiu um ramo do direito, o "Conflict of Law" especialmente dirigido a dirimir conflitos na esfera das jurisdições federal e dos Estados, e de conflitos no espaço entre as normas de tais sistemas. ${ }^{19}$

No ápice, encontra-se a Constituição dos EUA, aprovada por um Congresso Constituinte em 17 de setembro de 1787 e ratificada pelos Estados da Federação, em 1788. Suas dez primeiras emendas, elaboradas naquela época e em

19. Nos EUA, o "Conflict of Laws" é uma disciplina que se encontra nos dois grandes sistemas jurídicos existentes naquele país: a. os direitos dos Estados-membros (no sistema federativo norteamericano, com suas próprias legislações de direito privado e de direito público, inclusive processual e de organização judiciária, bem como de Direito Internacional Privado) e b. os direitos federais (que têm o mesmo campo de abrangência que os direitos dos Estados-membros). "International Private $L a w^{\prime}$, conquanto denominação cunhada por um professor norte-americano de Harvard, Joseph Story, para o direito que regula conflitos de leis no espaço, não se emprega usualmente nos EUA (sendo corrente na Inglaterra). Portanto, os conflitos no espaço de leis, nos EUA, podem significar tanto conflitos entre leis norte-americanas (entre as leis dos Estados federados ou destes e a lei federal), quanto entre estas leis e leis provenientes de Estados estrangeiros. Na Inglaterra, Estado de organização unitária, não se colocam tais problemas, típicos de uma federação, onde se confere grande autonomia às unidades federadas. Veja-se do prof. Peter Hay, "International versus Interstate Conflicts Law in the United States", In: 35 Rabels Zeitschrift für ausländisches und internationales Privatrecht, pp. 429-495 (1971). 
vigor a partir de 1789, são denominadas "Bill of Rights" e ela, até a presente data, sofreu um total de 26 emendas (que exigem a votação de 2/3 de ambas as casas do Legislativo e ratificação por 3/4 das casas legislativas dos Estados, sendo esta exigência passível de ser substituída por convenções entre os Estados). Espalhados por entre os dispositivos primitivos e as emendas posteriores, há princípios jurídicos e regras hermenêuticas e de aplicação, que se denominam clauses, em razão dos artigos ("clauses" são as denominações do que para nós seriam os "artigos") da Constituição: "Supremacy Clause" (superioridade da Constituição e da legislação federal sobre as constituições e a legislação dos Estados-membros, inclusive sobre os tratados internacionais); "Full Faith and Credit Clause" (obrigatoriedade de os Estados atribuírem aos "statutes" e "cases" de "sister states" o mesmo valor jurídico que os "statutes" e "cases" nascidos no próprio território); "Due Process Clause" (obrigatoriedade de a União e os Estados respeitarem os princípios fundamentais e constitucionais relativos a direitos a um processo civil e criminal onde se assegurem ampla defesa, o contraditório, a proibição de dupla condenação...), "Commerce Clause" (proibição de leis estaduais ou federais que criem empecilhos ao livre comércio de bens entre os Estados da União).

A seguir, encontram-se os tratados internacionais e os "Executive Agreements", que vêm logo abaixo da Constituição Federal, na hierarquia das leis. Em virtude da "Supremacy Clause", os atos internacionais são superiores às leis federais ("federal statutes") revogam-nos, mas são por elas revogáveis. Os tratados em devida forma, devem ter a aprovação de 2/3 do Senado Federal (assim devendo entender-se os tratados assinados pelo Executivo com Estados estrangeiros, e submetidos à aprovação do Senado). Os "Executive Agreements", ${ }^{20}$ igualmente atos internacionais bi ou multilaterais, são aqueles que não necessitam, para seu vigor interno nos EUA, da aprovação legislativa; quanto à obrigatoriedade de submissão de atos internacionais ao Senado Federal, inexiste dispositivo constitucional expresso, sendo dado que é bastante limitado o número de "Executive Agreements", que os "federal cases" e a doutrina têm considerado como aqueles que versam sobre uma competência exclusiva do Presidente, enquanto Chefe do Poder Executivo (e que dispensariam a remessa ao Senado dos EUA).

20. Veja-se nosso trabalho: "Agreements", "Executive Agreements", "Gentlemen's Agreements" In: Enciclopédia Saraiva de Direito, São Paulo, Saraiva, v. 5, pp. 246-281. 
"Federal Statutes" são as normas federais assim entendidas: $1^{\text {a }}$ os atos normativos elaborados com a participação do Executivo e do Legislativo, com suas duas Casas: a "House of Representatives" e o (Federal) "Senate"; denominam-se Act e, por vezes, levam o nome do deputado ou senador que the dá paternidade: "Shermmann Act" (uma das leis sobre antitruste), "Norris-LaGuardia Act (1932)" (primeira lei sobre relações trabalhistas), ou se denominam com os nomes que a própria lei manda chamar: "National Labor Relations Act" (também chamado "Wagner Act"); $2^{\mathrm{a}}$ os atos normativos elaborados pelo Poder Executivo (na sua competência exclusiva ou vinculada a um " $A c t$ "), diretamente (o Presidente com a cooperação dos "Departments", que são os nossos Ministérios) ou indiretamente, pelas inúmeras "Federal Agencies" (órgãos da Administração Indireta) com denominações que revelam mais sua finalidade do que a origem: Order, Administrative Rules (ou simplesmente Rules of...), Regulations; $3^{\text {a }}$ os atos normativos elaborados pela "Supreme Court", em especial em matéria de processo, devendo destacar-se o que seria o equivalente ao nosso Código de Processo Civil, vigente para os órgãos do Judiciário federal: as "Federal Rules of Civil Procedure of $1938^{\prime \prime}$

Abaixo do "US statutes" vêm os "States Statutes" "State Statutes" são as normas votadas na jurisdição do território dos Estados-membros, devendo dizer-se que são as mais detalhadas, uma vez que, como já se disse, a legislação federal é intersticial. Em outras palavras: a legislação federal é aquela criada pela União (e quando se quer isso acentuar, se diz que é uma "USA rule", um "US statute" e toda vez que aparecer as siglas US ou USA se sabe que se trata de algo federal), por mandamento direto da Constituição Federal, ou pelos poderes implícitos (implied powers), sendo dado que a legislação federal é superior à estadual ("federal statutes supersedes State statutes"), controle esse realizado pela Supreme Court numa maneira negativa (declaração de inconstitucionalidade por ter havido uma "unconstitutional intrusion by the State into the comprehensive federal competence"), é o chamado "negative control" ou, ainda, de maneira positiva, ao declarar que, num caso de competência concorrente entre União e Estado, a competência deste cessou, ou não existia, e que o legislador federal exerceu corretamente sua própria competência (é o que se denomina "preemption"). Tais controles são levados a cabo através do "writ of certiorari" ("mutatis mutandis" nosso recurso extraordinário). 
"States Statutes" são: as constituições dos Estados (devendo dizer-se que os Estados têm um Governor e um Legislativo bicameral: General Assembly e State Senate, sendo os órgãos do Judiciário compostos de maneira diferente, segundo cada Estado), os atos elaborados entre Executivo e Legislativo estaduais ("Acts"), ou só pelo Executivo ("Orders" "Administrative Rules" ou "Rules" e "Regulations") e pelos Judiciários Estaduais (a exemplo, muitos "Codes" em matéria processual). É mister não perder de vista que a federação norte-americana é bem diferente da brasileira, conforme será descrito mais além e, dada a maior autonomia dos Estados-membros nos EUA, muita matéria que no Brasil é de competência da União, é da competência dos Estados-membros naquele País, razão pela qual, a nossos olhos, a legislação dos Estados nos EUA é muito mais extensa, "ratione materiae", do que no Brasil.

Quanto à competência legislativa dos municípios, que tanto podem ser organizados como "municipalities" (correspondendo a uma cidade ou região metropolitana) ou "counties" (organização política territorial que engloba várias cidades, "towns" ou "regions") variando muito em cada "State" são regidos pela "Home Rule" (o equivalente à nossa "lei orgânica dos municípios") elaboradas de maneira mais diversa nos vários Estados (seja pelo legislativo estadual, seja pelos órgãos legisladores das unidades político-administrativas interessadas). Expedem-se a nível municipal (a melhor tradução para o termo é "local") "local ordinances" "local rules" e "local regulations". Em geral, nas "municipalities" e nos "counties" há um prefeito ("Mayor" e uma assembléia unicameral, o "Council"), reservando-se para o que denominamos "lei municipal", a apelação de "Municipal Ordinances"

\section{3. "Common Law" e "Civil Law"}

No sentido amplo, "Common Law" quer referir-se ao sistema da família dos direitos que receberam a influência do direito da Inglaterra (onde vicejam os contrastes apontados entre Common Law v. Equity Law e Common Law $v$. Statute Law) e de outro lado, o sistema da família dos direitos romanogermânicos, que igualmente se denominam "Civil Law", conforme apelação que os doutrinadores daquele sistema costumam conferir a esta última. Trata-se, portanto, agora, não de descrever o sistema da "Common Law", seus componentes, as relações "internae corporis", mas de descrever as relações intersistemáticas (de certa 
maneira, "internacionais") entre a "Common Law" e outros sistemas (que, neste estudo, se referem tão-somente ao sistema romano-germânico, com a exclusão dos outros: socialistas, religiosos, tradicionais etc.). Quanto ao que se entende por relações, a ênfase será no comparativismo, e não no sentido de cooperação e/ou confronto (o que, de igual forma, permitiria estudos de empréstimos de instituições entre os sistemas, de adaptações, de hermenêutica intersistemática). ${ }^{21}$

Há ainda as seguintes oposições conceituais no que diz respeito à expressão "Common Law" porém dentro do próprio sistema da "Common Law":

a. "Common Law" v. "ecclesiastical law" ou ainda "canon law" portanto, como sinônimo de direito civil, ou leigo, ou secular, por oposição a direito canônico; ${ }^{22}$

b. "Common Law" v. "criminal law" ou seja, direito civil, por contraste a direito criminal, sendo que no Brasil, no caso, o adjetivo correspondente a "Common Law" seria: "cível",;

c. "Common Law" v. "Roman Law or modern Civil Law" de pura sinonímia com o que temos expressado como "Common Law" v. sistema romanogermânico. $^{24}$

Contudo, o contraste no Direito brasileiro entre civil e militar, no direito dos EUA se expressa como os contrastes "Civil Law" v. "military law", ou,

21. Exemplo de tais estudos podem ser exemplificados com a análise de como interpretamos nós o "leasing" e como eles, da "Common Law", interpretam "boa-fé" nos contratos internacionais. Ou quais as diferenças de um mesmo instituto existente na "Common Law" e no sistema romano-germânico, como se indagar em que medida as "corporations" são as nossas sociedades anônimas, ou a que instituto da "Common Law" corresponderia a nossa sociedade de responsabilidade limitada, etc.

22. "Ecclesiastical law" ou "canon lav", refere-se ao direito leigo, secular, definindo-se, portanto, a "Common Law" como "the system of jurisprudence administered by purely secular tribunals" (Black's, verbete: "Common Law").

23. O Black's no verbete: "Common Law" action", assim se expressa: "a civil suit, as distinguished from a criminal prosecution, or a proceeding to enforce a penalty or a police regulation; not necessarily an action which lies at Common Law" Kirby v. Railroad Co, C.C. lowa, 106 F.55I; US.V. Bolck 24 Fed.Cas. 1174. Em nossa metalinguagem, ficaria assim traduzido: Common Law action" é uma ação civel, distinta de uma ação criminal ou de procedimentos para aplicar uma penalidade ou um regulamento de polícia; não necessariamente uma ação que seja regulada pelo direito nascido das cortes de Westminster na Inglaterra (em oposisão a "Equity"). Sendo assim, conforme se pode ver, "Common Lav:" pode, então, ser sinômino de "civel", no vocabulário forense brasileiro, por oposição a criminal

24. Nos EUA, em geral, "Roman Law" è a denominação para o Direito Romano, tal qual, cientificamente, é estudado na doutrina elaborada na família dos direitos romano-germânicos, ou seja, a sua essência e as suas influências em ambos os sistemas da "Common Law" e da "Equity Law" e as marcantes influências no seu processo civil. 
em caso muito especial: "Civil Law v. martial law", (e não "Common Law" v. "military law". nem "Common Law" v. "martial law"), o que pode ser extraído do conceito "civil war" (aquela levada avante por forças oponentes no mesmo país; "internecine war" em contraste com "international war"). ${ }^{25}$ Isto posto, segue-se que no direito dos EUA "Civil Law" se opõe a "military law". entendido este como as normas de caráter disciplinar que regem o pessoal profissional a serviço do Governo dos EUA, nas suas forças armadas federais, portanto, "The Army", "The Navy" e "The Air Force" e o pessoal a seu serviço (e portanto, também o "military service"), em tempo de paz, ou em teripo de guerra, mas uma legislação ordinária. A oposição entre "Civil Law" v. "martial law" deve ser considerada, pelo fato de este reger tanto civilians" quanto "soldiers" e o país inteiro, sendo uma legislação absolutamente excepcional, que pode ab-rogar até mesmo as regras da Constituição ("it is over and above all of them"!).

Enfim, outra acepção do conceito "Common Law" é intrigante, como aparece no instituto "Common Law marriage". Trata-se do casamento de facto, ou como também se diz nos EUA, "informal marriages". reconhecido em todos os seus efeitos, havendo alguns requisitos, como: promessa de casamento, coabitação de fato, representação de terceiros ou mera apresentação à comunidade do casal como marido e mulher, e assunção de casamento, como se fosse válido, por pessoas da comunidade. Tal instituição faz mais pensar na "Equity"; por outro lado, a

25. O Black's no verbete "military jurisdiclion", transcreve as definições conforme US v. Minoru Yasui, CC Or., 48 F. Supp. 40. 46,47, em grandes linhas: $1^{\circ}$ jurisdiction under military lav: aplicação em tempo de guerra ou de paz das normas federais que prescrevem "articles of war"; $2^{\circ}$ "military government" em tempo de "foreign war" (guerra externa) além das fronteiras dos EUA ou em tempo de rebelião ou guerra civil, dentro do território dos EUA ou dos territórios ocupados por rebeldes considerados beligerantes; o "military Government" substitui o direito local e é levado a cabo por um comandante militar, sob a direção do Presidente dos EUA e a sanção expressa ou implícita do Congresso; $3^{\circ}$ "martial law", nas situações de invasão estrangeira ou de insurreição grave dentro do pais, ou durante rebelião nos limites dos Estados que mantenham adesão ao "Governo Nacional"; normas votadas pelo Congresso, ou, excepcionalmente, pelo presidente dos EUA, em caso de perigo iminente e justificável, "where ordinary lav no longer adequately secures public safety and private rights" O "martial law". portanto, é aplicado pela "Court Martial", nos excepcionais casos de guerra externa ou de crimes que extrapolem os casos previstos em tempos de paz, aplicado por autoridades militares, nas situações em que estas "exercem o governo ou vários graus de controle sobre civis ou autoridades civis no território doméstico", Ochikubo v. Bonesteel D.C.Cal., 60 F. Supp. 916, 928, 929, 930. No verbete martial lanv, ao transcrever-se conceitos ligados ao mesmo, o Black's mostra o contraste entre "Civil Law" e "martial lanv": martial law is neither more or less than the will of the general who commands the army. It overrides and supresses all existing Civil Law, civil officers, and civil authorities, by the arbitrary exercise of military power... Martial law is regulated by no known or established system or code of lavs, as it is over and above all of them... In re Eagen, 5 Blatchf.321, F.Ca.NQ 4,303 (verbete: "martial law", com ênfase não do original transcrito). 
informalidade existente nos "common-law marriages" estaria a indicar uma criação jurisprudencial da "case law", por certo para evitar os formalismos criados pela "Statute Law" Certamente, porém, a expressão não pode ser reservada a um instituto que seria típico do sistema da "Common Law". pois, em graus variáveis, o casamento de facto existe nos sistemas romano-germânicos. Registre-se, assim, mais essa acepção do adjetivo "Common Law"

Conforme já foi anunciado, na sua origem, a "Common Law" (entendida esta expressão como "família de direito". por oposição à família romanogermânica) é "English", porquanto nascida na Inglaterra e com a expansão pelo mundo da cultura e civilização daquele país; hoje, a grosso modo, se pode dizer que aquele sistema de direito se encontra nos países de fala inglesa (devendo notar-se que, enquanto o latim era a língua judiciária na Europa Continental, o normando e, posteriormente, o latim e o francês passaram a ser as línguas forenses, até 1731, com a adoção do inglês como língua oficial. ${ }^{26}$ Seu início coincide com a conquista da Inglaterra pelos normandos, chefiados por Guilherme, o Conquistador, que se tornaria Guilherme I da Inglaterra, o qual proclamaria, em 1066, a continuidade dos direitos anglo-saxônicos, que já existiam na ilha desde antes mesmo da formação do Reino da Inglaterra, em meados do século X, semibárbaros e costumeiros, conquanto impusesse o direito normando. Em meados do século XII, os normandos conquistam a ilha da Irlanda, para lá carregando o feudalismo e o cristianismo; posteriormente, é a vez, em meados do século XIII, da proclamação da "overlordship" inglesa sobre o País de Gales. Durante o reinado dos Tudors, consolida-se o poder inglês na Irlanda, e após a morte da Rainha Elizabeth I, sem herdeiros, sobe ao trono inglês, o Rei Jaime VI da Escócia, que passaria a ser Jaime I da Inglaterra, realizando-se uma união pessoal entre ambos os países. Na verdade, a Escócia nunca chegou a ser dominada pela Inglaterra, o que, talvez, explique este país estar excluído do rol daqueles que compõem a família da "Common Law"; em 1707, proclama-se a união real da Inglaterra e Escócia, formando-se o que se denominou a Grã-Bretanha. Quanto à ilha da Irlanda, foi dominada pelos ingleses na sua totalidade até os inícios do século XX, desmembrada em duas partes, em 1921, com a criação do "Irish Free State", em 4/5 da ilha, continuando sua parte norte sob a dominação inglesa; posteriormente, o citado "Irish Free State" passou a denominar-se República da Irlanda, e, com a adoção de uma constituição naquela data, adotou o nome gaélico de 
Eire, continuando, contudo, com seu sistema jurídico que é a "Common Law" Em conseqüência, adotou-se a denominação oficial daquele complexo, na atualidade, que é "United Kingdom of Great Britain and Northern Ireland", ou seja, o Reino Unido da Grã-Bretanha e da Irlanda do Norte, ou Reino Unido, "tout court" cuja sede é Londres e Governado por uma Monarquia Parlamentar. O Eire, ou República da Irlanda, é um Estado independente, que adota a "Common Law" e onde se fala o "Irisch" e o inglês.

Sendo assim, são incorretas as denominações que se seguem para designar a "Common Law": não é um direito anglo-saxônico (pois este era o direito das tribos e reinos da Inglaterra, antes da conquista normanda no século $\mathrm{X}$, e que conviveria com a "Common Law" nos seus primórdios e que até hoje pode ser invocado em matéria de usos estritamente locais na citada Inglaterra); igualmente não é direito inglês, porque engloba outros países independentes, como a República da Irlanda (Eire) e vários outros, como os EUA.

Outra incorreção é dizer que a "Common Law" seria um direito costumeiro. Aqui é necessária uma precisão de natureza teórica, pois há quem considere a jurisprudência como um costume, (repetição de julgados com a convicção de representarem uma regra jurídica) falando mesmo na existência de um costume judiciário, em comparação ao costume geral (aquele que o povo praticaria). A incorreção reside em razões de ambos os sistemas: na "Civil Law", é bem verdade que "uma ínica andorinha não faz verão" e que, portanto, um caso isolado, propriamente, não-constitui jurisprudência; por outro lado, sua eventual força normativa advém não da "communis opinio juris" do povo, mas do prestígio do órgão que permite a formação da jurisprudência, sem, no entanto, apresentar o caráter de obrigatoriedade que os casos julgados têm na "Common Law" ou que os costumes representam no Direito Internacional Público e no Direito do Comércio Internacional (onde as lacunas são enormes, por falta de um legislador de normas escritas, o que permite ver-se o costume como fonte de primacial importância, exatamente pelas lacunas existentes, dada a mencionada falta). Na "Common Low", um único julgado é considerado como precedente obrigatório, pois declara a existência de uma norma jurídica, para o "fattispecie" sendo, portanto, a jurisprudência a fonte primeira formal do direito; as relações entre o direito costumeiro, "customary law" e a "Common Law" (entendido como direito declarado pela autoridade e não aquele que espontaneamente é praticado pelo povo) são as mesmas suscitadas entre o "jus scriptum" e o "jus non scriptum" do sistema romano- 
germânico: necessidade de prova, reserva a seu possível valor derrogatório do direito estatal a determinados campos do direito comercial, do comércio internacional, e do Direito Internacional Público, e, sobretudo, de um valor localizado no espaço. Na Common Law, em especial após a reforma do direito comercial empreendida por Lord Mansfield na Inglaterra, pelos anos a partir de 1776 (data de sua indicação para o cargo de Chief Justice do "King's Bench"), ao ter estendido a aplicação do mesmo para além da comunidade dos comerciantes (até então um direito estamental, a "Lex mercatoria" ou "ley merchant"), o costume se encontra reservado a matérias locais e restrita a assuntos comerciais.

Isto dito, é mister enumerar os principais países que pertencem à famíla da "Common Law": Austrália, Nova Zelândia, Canadá (Província de Quebec), Índia, Paquistão, Bangladesh, Quênia, Nigéria, Hong Kong, Guiana, Trinidad Tobago e Barbados, dentre outros. Os EUA, salvo o Estado da Luisiana, são considerados um sistema misto, conquanto pertencente à "Common Law" (e a Escócia, Israel, África do Sul e Filipinas, países de sistema misto, pertencentes à família romano-germânica). Nos EUA, as antigas possessões espanholas, como a Califórnia e o Texas, embora reflitam, em alguns aspectos dos direitos de família algo das leis dos antigos colonizadores, certamente são do sistema da "Common Law"; a Luisiana, contudo, dentro dos EUA, é o único Estado da Federação que se conservou fiel aos primeiros colonizadores franceses e espanhóis, uma vez que pertence à família dos direitos romano-germânicos (da mesma forma Porto Rico, que é um Estado-associado).

Interessante observar, igualmente, que, dada a predominância do "case law" na "Common Law", o sistema se torna em grande parte muito mais nacionalista que os da família romano-germânica (veja-se, em particular, o papel, de certa forma relevante, da doutrina estrangeira no Direito brasileiro). Até fins do século passado, alguns "cases" ingleses eram citados nos EUA; hoje, conforme constaram os autores norte-americanos consultados para este trabalho, nenhuma influência a "Common Law" inglesa exerce nos EUA. Contrariamente, é do conhecimento do autor que na Inglaterra, pelo menos em matéria de responsabilidade civil extracontratual ("torts"), tẹm havido, com alguma frequiência, invocação do "leading case" Babcock v. Jackson nos julgados ingleses (responsabilidade civil por acidente com automóvel). 
6. Conclusões.

$\mathrm{Na}$ "Common Law" a idéia que permeia o sistema é de que o direito existe, não para ser um edifício lógico e sistemático, mas para resolver questões concretas. Antes de examinar se existe ou não algum geometrismo no sistema, este se preocupa com os remédios: "reliefs and remedies", e, tanto é assim, que se chegou ao absurdo de não-permitir uma ação frente ao Judiciário se não houvesse um writ que fornecesse a solução prática (e conforme visto, tal fato foi em parte, corrigido pela "Equity").

Isto posto, ressalta-se, de imediato, o papel secundário da doutrina abstrata, em favor das soluções pragmáticas. Na Inglaterra, o papel da Universidade sempre foi insignificante na formação do direito ou na formulação de teorias generalizantes. A prova é que os estudos de Filosofia do Direito, tanto na Inglaterra quanto nos EUA, se denominam "Jurisprudence", ou seja, abstrações a partir de casos julgados! Embora as Universidades tenham sido bastante importantes nos EUA, como papel fundamental de legitimação dos agentes junto ao Poder Judiciário (e inclusive na formação dos quadros do próprio Judiciário), apenas indiretamente, pela participação de seus professores e entidades de estudos de uniformização de normas jurídicas, é ela algo relevante na formação da norma jurídica. O papel da doutrina é extremamente limitado, e se citam os raros casos em que estudos doutrinários tiveram alguma influência em "overruling" a jurisprudência. É bem verdade que nos EUA se exige o grau universitário e um exame da "American Bar Association" (o equivalente à nossa $\mathrm{OAB}$ ) para exercer a advocacia, (ao contrário da Inglaterra onde tal legitimação é dada pelos clubes privados, os Inns of the Court), mas a indicação para determinadas funções, como as de Prosecutor, dispensam aquela formação.

Nesta ordem de considerações, a simbiose que existe na família romano-germânica entre a Universidade e a Justiça, pode-se dizer que na "Common $L a w "$ a tal simbiose se encontra plenamente verificável entre "the bench and the bar" (os coletivos abstratos para designar a barra, ou a cerca, que separa de um lado os juízes e seus auxiliares, e de outro, os advogados e seus coadjutores, na Inglaterra deste lado, melhor dito, os práticos e seus coadjutores.

Inútil buscar uma imagem de figura geométrica, pelo menos na geometria cartesiana, que permita descrever a "Common Law"; se existe um figura que se possa aproximar à mesma, seria a de uma colcha-de-retalhos, que cumpre, à perfeição, sua finalidade, que é dar abrigo à sociedade, e pensar os seus ferimentos, 
representados em violações da paz social. Só mesmo um espírito geométrico, como um mestre francês, poderia descrever o "esprit de finesse" que permeia a "Common Law". como o faz o prof. René David, ${ }^{27}$ verbis: "Nos países de direito escrito, em que o direito se apresenta principalmente sob a forma dum direito legislativo, as regras de direito são formuladas com uma tal generalidade, que o apelo à razão se processa, normalmente, no quadro das fórmulas gerais, sob a forma de aplicação $e$ interpretação destas regras; a existência de lacunas na ordem legislativa é dificilmente reconhecida; mais do que para completar a ordem jurídica, a razão desempenha uma função na interpretação da lei. Num sistema jurisprudencial, como é o direito inglês, a situação apresenta-se muito diferente. $O$ aspecto casuístico, que então reveste o direito, deixa subsistir, de forma intencional, muitas lacunas; e a razão é francamente reconhecida como uma fonte subsidiária do direito, chamada a preencher estas lacunas. A uma técnica de interpretação do direito, substituiu-se uma técnica de distinções, visando a estabelecer regras novas, cada vez mais precisas, em vez de aplicar uma regra preexistente. Os sistemas de direito da familia romano-germânica são sistemas fechados, a "Common Law" é um sistema aberto, onde novas regras são continuamente reveladas; estas novas regras fundam-se na razão" (Op. cit., pp. 467-8).

É igualmente este gosto pela regra abstrata e geral, que está presente na família romano-germânica dos Direitos, e que poderia explicar a redação de monumentos legislativos como os códigos. Para um analista provindo da "Common $L a w^{\prime \prime}$ as normas assim elaboradas e escritas parecem, antes, preceitos morais, regras religiosas, do que normas jurídicas precisas e claras, destinadas a solucionar conflitos no interior de uma sociedade.

A abertura apontada pelo prof. René David na "Common Law" poderia muito bem explicar o detalhismo existente nos "statutes", conforme demonstramos anteriormente, e, de igual forma, nos contratos civis ou comerciais, redigidos em grandeza enciclopédica, que nada mais refletem senão o aspecto casuístico do sistema. Torna-se, pois, impossível encontrar um correspondente a Hans Kelsen, ou mesmo um Savigny entre os doutrinadores da "Common Law" nem mesmo um dos discípulos críticos deste último, Karl Marx (que teve a ingenuidade de pensar que o sistema capitalista forjaria sua própria destruição, pelas contradições internas, sem ter-se dado conta da plasticidade do sistema inglês; na verdade, não foi

27. O autor do presente trabalho, consciente de estar sendo guiado pela metalinguagem formada num sistema romanistico, como o brasileiro, apoiou-se no contraste entre "esprit de géometrie" e "esprit de finesse", conforme as Pensées de Pascal. 
na Inglaterra, como erroneamente previsto, que se verificou a revolução do proletariado, mas na Rússia Imperial, então um sistema inteiramente configurado como integrante do sistema romano-germânico!).

Por muito sedutor que seja o uso da indução ${ }^{28}$ nas argumentações judiciárias, os próprios doutrinadores da "Common Law" apontam seus defeitos, como o faz o prof. Farnsworth; defeitos maiores esses que se resumem, no que aquele professor da Columbia University School of Law, denomina "two puzzles in precedents": $1^{\circ}$ o valor a ser dado a um "multilegged holding" e $2^{\circ}$ os efeitos retroativos de um julgado que "overrules a prior decision". No primeiro caso dos precedentes que se baseiam em várias razões (por ex.: as decisões com votos dissidentes, os quais, embora dêem provimento a um recurso, discordam quanto a algumas razões do acolhimento da medida, seguidas pela maioria; ilustrativamente: num recurso baseado em três razões, no qual o acolhimento foi lastreado apenas em uma): pode ser argumentado que nenhuma das razões era suficiente para reforma da sentença recorrida, uma vez que as razões, tomadas isoladamente, eram suficientes para a decisão, ou ainda, que a decisão, inteira, não-contém um "holding" mas é apenas um "dictum" Na verdade, ainda segundo a observação daquele Professor de Columbia, é mais do que certo que uma decisão fica mais firmemente estabelecida numa única razão, do que em razões alternativas! Quanto ao segundo quebracabeças, a questão da retroatividade do precedente nos "case lows" ou seja, nos acórdãos (fato impossível de acontecer entre nós, dado que um julgado decidido em circunstâncias iguais a outro, que teve decisão contrária, não coloca o problema de revogação da norma), mas plenamente viável na hipótese da "Common Law", em que um "case law" ab-roga outro "case law" e em que a norma é "judge-made" Um

28. A indução, argumentação dominante na "Common Law", é definida como aquela que conclui pelo particular, seja aquela do tipo generalizadora (parte do particular, vai ao geral e conclui pelo particular), seja a analógica ou empírica (que parte de um particular e conclui outro particular). No primeiro tipo, conforme nos ensina a Lógica Menor, o predicado que convém ao particular equivalente ao geral, convém ao geral, caso em que o particular deve ser suficientemente enumerado, para poder equivaler ao geral; no caso da indução empírica ou analógica, o princípio é de que o predicado, que se diz de um sujeito semelhante a outro, se diz deste outro, com probabilidade. Na indução empírica ou analógica, distinguem-se as espécies: $1^{\circ}$ indução a pari (baseada na semelhança positiva, e de paridade : a casu pari ad-casum pare; $2^{\circ}$ indução a contrário (na hipótese de ir-se de um caso contrário a outro contrário, ou seja, estabelecendo-se os extremos da mesma espécie; $3^{\circ}$ indução $a$ fortiori (vai-se de uma caso mais forte para um menos forte, sendo que o caso menos forte é aceito, com maioria de razão), que num "case law", se apresentaria da seguinte forma: no "leading case" $\mathrm{XYZ}$, num acidente automobilistico, houve danos pessoais leves e o causador foi obrigado a pagar indenização de $N$ moedas (caso forte); no caso "sub studio". num acidente automobilistico, houve morte da vitima (caso menos forte) e, portanto, a fortiori, a indenização deverá ser de $N+n$ moedas, apoiado com maioria de razão. 
exemplo ilustraria: $A$ firma um contrato $\operatorname{com} B$ e com $C$, absolutamente idênticos; ajuizada uma ação de $A$ contra $B$, e havendo julgamento de que o "leading case" não mais se aplica à espécie (ou, em outras palavras, tendo havido ab-roga da norma); quais seriam as conseqüências do precedente para a validade do contrato entre $A$ e $C$ !? Na verdade, as questões de conflitos de normas no tempo, o Direito Intertemporal, dada a extrema fluidez e plasticidade da norma jurídica no sistema da "Common Law" suscitam questões de grande complexidade, que inexistem no sistema da família romano-germânica, onde impera, com muita nitidez, os momentos de entrada em vigor da norma jurídica e onde os direitos adquiridos (a la Gabba) ou, estes, o ato jurídico perfeito e a coisa julgada (Constituição brasileira) ou a situação jurídica constituída (à la Roubier), são definidos com rigor.

Enfim, na comparação dos sistemas da família romano-germânica dos direitos e da "Common Law" reafirme-se o postulado de que não é permitido, em Direito Comparado, estabelecerem-se juízos de valor quanto a este ou aquele sistema, uma vez que ambos são criaturas da cultura e da civilização e plenamente cumprem com as funçōes para as quais o engenho humano os criou: proteger e salvaguardar a sociedade humana. Se os juristas e advogados da família romanogermânica olham com certa emulação a adequação dos "case laws" à realidade, advogados e juristas da "Common Law" sentem uma certa nostalgia, em face da harmonia e racionalidade dos códigos! Na essência é o velho contraste indução/dedução, ambos métodos válidos! No fundo, tanto a dedução quanto a indução, constituem-se em métodos científicos de conhecimento, aquela aplicável às ciências especulativas, esta às ciências práticas, porém não com exclusividade, pois na Física ou na Biologia existe a utilização de ambos os processos metodológicos. Nas ciências do comportamento do homem (que trabalham tanto com juízos de realidade, quanto com juízos de valor), o intercâmbio de ambos os métodos é ainda mais necessário, inclusive como condição de verificação de provas das afirmações, sob pena de falseamento dos postulados científicos, seja por uma generalização inexistente, ao que pode levar o abuso da indução; seja por um abstracionismo que descreva o mundo dos homens, como se fosse constituído de seres perfeitos e angelicais (o grande risco do abuso dos processos dedutivos).

Ou em outras palavras, tanto a pirâmide kelseniana abstrata, quanto a colcha de retalhos casuística, constituem criações engenhosas do homem, os sistemas jurídicos nacionais, concebidos para a salvaguarda e aperfeiçoamento da sociedade humana. 